\title{
Prevalence of stammering among internally displaced population in North Waziristan Agency
}

Mehtab Khatoon, ${ }^{1}$ Nazia Mumtaz ${ }^{2}$ and Ghulam Saqulain ${ }^{3}$

${ }^{1}$ FATA Secretariat, Orakzai, Pakistan. Faculty of Rehab \& Allied Health Sciences, Riphah International University, Lahore. Pakistan. ${ }^{3}$ Capital Hospital, Post Graduate Medical Institute, Islamabad, Pakistan (Correspondence to: G. Saqulain: ghulam_saqulain@yahoo.com).

\begin{abstract}
Background: Stammering is a dysfluency disorder that is common in children exposed to stressful conditions. Displacement from home is one such situation. There is a large internally displaced population in Pakistan.

Aims: To determine the prevalence of stammering among children of internally displaced persons (IDPs) in North Waziristan Agency, Pakistan.

Methods: This cross-sectional survey included 400 Pushto-speaking children of IDPs, aged 5-18 years enrolled from schools in North Waziristan Agency, from July 2017 to July 2018. The Fluency Rating Scale was used for speech assessment. Data were analysed by SPSS version 20.

Results: The prevalence of stammering was $11 \%$, with moderate stammering being more prevalent. Five (5.6\%) girls and $39(12.5 \%)$ boys were identified with stammering.

Conclusions: Stammering is highly prevalent among IDPs.

Keywords: disasters, internally displaced persons, prevalence, stammering, speech disorders.

Citation: Khatoon M; Mumtaz N; Saqulain G. Prevalence of stammering among internally displaced population in North Waziristan Agency. East Mediterr Health J. 2020;26(8):982-986. https://doi.org/10.26719/emhj.20.011

Received: 10/10/18; accepted: 29/04/19

Copyright $@$ C World Health Organization (WHO) 2020. Open Access. Some rights reserved. This work is available under the CC BY-NC-SA 3.0 IGO license (https://creativecommons.org/licenses/by-nc-sa/3.0/igo)
\end{abstract}

\section{Introduction}

Stammering/stuttering is a speech disorder in which speech may become dysfluent and its time pattern may be affected (1). Stammering is characterized by repetitions, pauses, unnecessary production of vowels and unintentional breaks, spasms and emotional swings during speech production, making it unintelligible. Thus, people with stammering face significant problems in communicating during routine interactions (2).

Stammering can occur at any age (1), although it typically starts in preschool years, suggesting that factors during child development are involved. Usually, both genetic and environmental factors are incriminated, with genetic factors such as dopamine imbalance (1) interacting with environmental factors. The latter include family, learning and socioeconomic conditions, which all may be psychological causes of stammering (3). Children are more prone to stressful situations, and develop anxiety in situations such as parental conflict, displacement from home, and separation from siblings. Furnham and Davis concluded that "social and emotional factors appear to be crucial to the onset and maintenance of stuttering" (4). Children with anxiety or those who are prone to situations like social anxiety, where they are evaluated by others; or children with separation anxiety or generalized anxiety disorder may have dysfluent speech with panic. These anxiety situations are all present in displacement situations.
Cohen noted that internally displaced persons (IDPs) are: "Persons or groups of persons who have been forced or obliged to leave their homes or places of habitual residence, in particular as a result of or in order to avoid the effects of armed conflict, situations of generalized violence, violations of human rights or natural or human-made disasters, and who have not crossed an internationally recognized state border" (5). According to Peek, in disaster situations, populations face psychological stress or trauma, with children being more prone to developing psychological problems (6). Children who are experiencing psychological stress, such as inappropriate family attitudes, children with broken families, moving from one place to another, loss of a beloved one or even a pet, family vacations, or conflict among siblings may develop stammering (7). According to Yairi and Ambrose, the impact of race, ethnic origin, culture, bilingualism, and socioeconomic status on the incidence/prevalence of stammering remains uncertain (8). Ajdacic-Gross et al. reported that there was no overwhelmingly strong risk factor for stammering (9).

There is a large internally displaced population in Pakistan because of terrorism and counter-terrorism activities, which may have resulted in an increase in emotional, psychological and communication disorders, such as speech disorders, especially stammering. To the best of our knowledge, there has been no study from this part of the world on this important health issue. Therefore, the current study was designed to determine the prevalence of stammering in IDPs in North Waziristan 
Agency, Pakistan. This study is important since such large numbers of IDPs are rarely seen in any part of the world. Our results are important for rehabilitation by early identification, thus leading to timely intervention and resource allocation in such locations.

\section{Methods}

This was a cross-sectional survey carried out to determine the prevalence of stammering among children of IDPs attending schools in North Waziristan Agency. The study comprised 400 children of registered IDPs whose native language was Pushto. There were 312 (78\%) boys and $88(22 \%)$ girls with a male to female ratio of $3.54: 1$, aged 5-18 years (Figure 1). They were enrolled through convenience sampling after obtaining consent for inclusion in the study. Children with other disabilities were excluded. The study was conducted over a period of 1 year from July 2017 to July 2018.

The Fluency Severity Rating Scale was administered in one-to-one sessions to investigate the prevalence of stammering among IDPs, and a score of $<4$ was considered normal, whereas scores of 4, 5-6 and 7-9 were labelled mild, moderate and severe stammering, respectively.

Data were collected, coded and analysed with SPSS version 20. Variables studied included sex, age group and stammering severity, and were presented by absolute and relative frequency and $P$ values were calculated.

\section{Results}

There was a high prevalence of stammering among children of IDPs $(n=44,11 \%)$. The prevalence was $12.5 \%(n=39)$ among boys, compared with 5.6\% $(n=5)$ among girls (Figure 1), with a male to female ratio of 7.8: 1. As regards the severity of stammering, moderate stammering was predominant in boys (69.23\%), followed by severe stammering $(20.51 \%)$, while in girls, moderate stammering predominated with a relative frequency of $80 \%$, followed by mild stammering $(20 \%)$, with no case of severe stam-

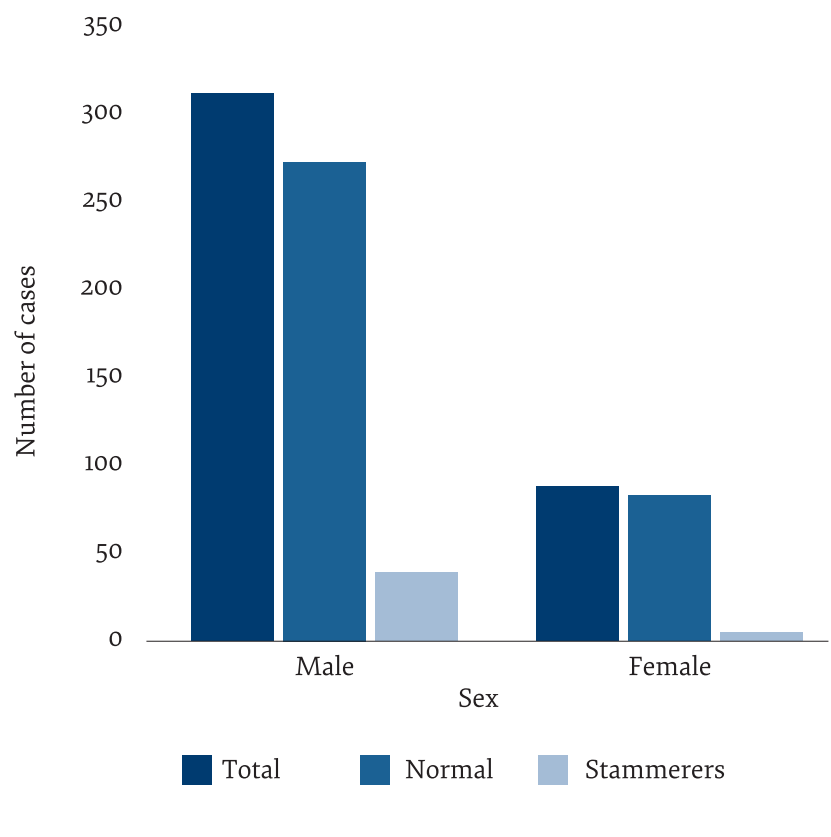

Figure 1 Gender distribution of study population $(n=400)$

mering; however, the sex difference was not significant $(P=0.17)$ (Table 1).

The study population was divided into 2 age groups. The prevalence of stammering in age group 5-11 years was $10.49 \%$ (28 affected cases out of 269), while in the age group 12-18 years, prevalence was $12.03 \%$ (16 affected cases out of 133) (Figure 2). As regards severity, moderate stammering predominated in both groups, with a relative frequency of $71.43 \%$ in the $5-11$ years age group and $68.75 \%$ in the $12-18$ years age group. The difference between age groups and severity of stammering was not significant $(P=0.62)$ (Table 1$)$.

\section{Discussion}

In the present study the prevalence of stammering among children of IDPs was $11 \%$ (44 children) with a higher prevalence among boys of $12.5 \%(n=39)$ compared with girls $(5.6 \% ; n=5)$, with a male to female ratio of $7.8: 1$.

Table 1 Severity of stammering according to age group and sex $(n=44)$

\begin{tabular}{|c|c|c|c|c|c|c|c|c|c|}
\hline \multirow{3}{*}{ Variable } & \multicolumn{6}{|c|}{ Stammering severity } & \multirow{2}{*}{\multicolumn{2}{|c|}{ Total }} & \multirow{3}{*}{$\chi^{2}$} \\
\hline & \multicolumn{2}{|c|}{ Severe } & \multicolumn{2}{|c|}{ Moderate } & \multicolumn{2}{|c|}{ Mild } & & & \\
\hline & n & $\%$ & n & $\%$ & n & $\%$ & n & $\%$ & \\
\hline \multicolumn{10}{|l|}{ Sex } \\
\hline Male & 8 & 20.51 & 27 & 69.23 & 4 & 10.26 & 39 & 88.64 & \multirow{3}{*}{$\begin{array}{c}\chi^{2}(3)=5.01 \\
P=0.17\end{array}$} \\
\hline Female & o & 00.00 & 4 & 80.00 & 1 & 20.00 & 5 & 11.36 & \\
\hline Total & 8 & 18.18 & 31 & 70.46 & 5 & 11.36 & 44 & 100 & \\
\hline \multicolumn{10}{|c|}{ Age group, yr } \\
\hline $5-11$ & 4 & 14.28 & 20 & 71.43 & 4 & 14.29 & 28 & 63.64 & \multirow{3}{*}{$\begin{array}{c}\chi^{2}(3)=1.74 \\
P=0.62\end{array}$} \\
\hline $12-18$ & 4 & 25.00 & 11 & 68.75 & 1 & 6.25 & 16 & 36.36 & \\
\hline Total & 8 & 18.18 & 31 & 70.46 & 5 & 11.36 & 44 & 100 & \\
\hline
\end{tabular}




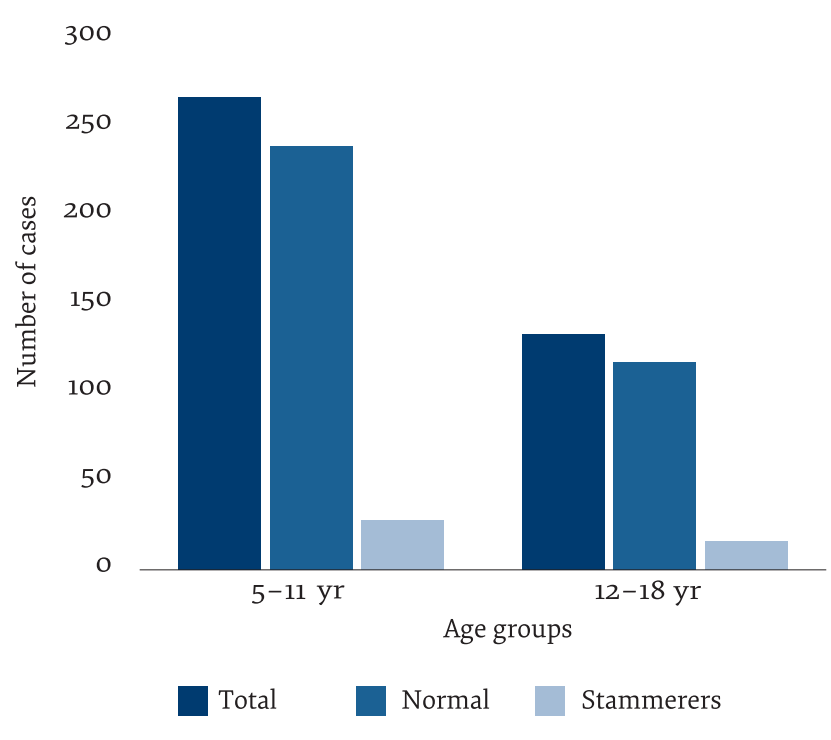

Figure 2 Age group distribution of study population $(n=400)$

A literature search did not reveal any studies on prevalence of stammering among IDPs; however, the prevalence in the current study was higher $(11 \%)$ than that found in different studies in non-IDP populations including a study from the Islamic Republic of Iran, which showed a prevalence of $0.72-1.5 \%(10-12)$, and a study on 10425 children, aged 5-12 years reported a prevalence of only $0.33 \%(13)$. The high prevalence of stammering in the current study could be attributed to adverse social and emotional factors due to the displacement situation that this population faced. According to Furnham et al., social and emotional factors appear to be crucial to the onset and maintenance of stammering (4). Also, in a local study in Lahore, Pakistan, involving children aged 5-17 years with speech disorders, prevalence of stammering was $24 \%$; however, this cannot be taken as a high prevalence of stammering because the sample population had speech disorders (14).
In the current study there was a high prevalence of stammering in boys, with a male to female ratio of 7.8: 1 . Although most studies have reported higher prevalence of stammering in boys than girls, in contrast to our study, the male to female ratio was lower, ranging from 2.1: 1 to 2.8: 1 in studies from the Islamic Republic of Iran $(11,12)$, Pakistan (14) and Brazil (15).

Adriaensens et al. found that severe stammering has a negative influence on adolescents' social acceptance, competence at school, formation of close friendships, and self-esteem (16). In the current study, among the 44 children with stammering, $8(18.18 \%)$ had severe stammering, $31(70.46 \%)$ moderate stammering and $5(11.36 \%)$ mild stammering. O'Brian et al. noted a significant negative correlation between achievement of the highest educational levels and stammering severity (17).

In our study, the prevalence of stammering was $10.49 \%(n=28)$ for children aged $5-11$ years and $12.03 \%$ $(n=16)$ for those aged 12-18 years. These findings are higher than those reported by Keating et al. in a study in Australia of 12388 children, aged 0-14 years (18). They found a maximum prevalence of $6.5 \%$ in boys aged 5 years and $1.8 \%$ in girls aged $3-4$ years, with overall prevalence of $1.7 \%$ in children aged $0-14$ years. We studied children aged 5-14 years. Also, Yairi and Ambrose (2) noted that risk of stuttering onset has usually passed by age 5 years, which is earlier than previously thought. De Oliveira et al. reported a high risk of developmental familial stammering at age 3-11 years (15).

\section{Conclusions}

Stammering was highly prevalent in children of IDPs in North Waziristan Agency, Pakistan, who were traumatized and living under stressful conditions. Although both sexes were affected, the prevalence in boys was higher than in girls.

Funding: None.

Competing interests: None declared.

\section{Prévalence du bégaiement chez les populations déplacées internes dans l'agence du Waziristan du Nord}

\section{Résumé}

Contexte : Le bégaiement est un trouble de l'élocution fréquent chez les enfants exposés à des conditions stressantes. L'éloignement du domicile fait partie de ces situations. Le Pakistan compte un grand nombre de déplacés internes.

Objectifs : Déterminer la prévalence du bégaiement chez les enfants des déplacés internes dans l'agence du Waziristan du Nord (Pakistan).

Méthodes : La présente enquête transversale portait sur 400 enfants de personnes déplacés internes, parlant le pashto, âgés de 5 à 18 ans et inscrits dans des établissements scolaires de l'agence du Waziristan du Nord, de juillet 2017 à juillet 2018. L'échelle d'évaluation de la fluidité verbale a été utilisée pour évaluer l'élocution. Les données ont été analysées à l'aide du logiciel SPSS (version 20).

Résultats : La prévalence du bégaiement était de $11 \%$, le bégaiement modéré étant le plus fréquent. Cinq filles (5,6 \%) et 39 garçons (12,5\%) ont été identifiés comme bégayant.

Conclusions : Le bégaiement est très répandu chez les populations déplacées internes. 


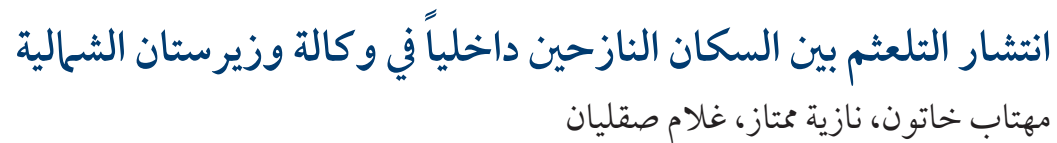

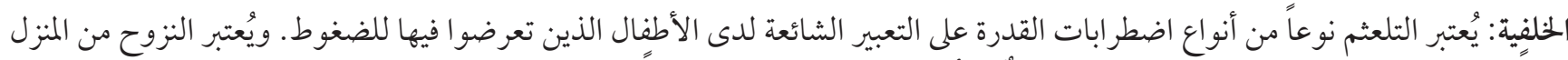

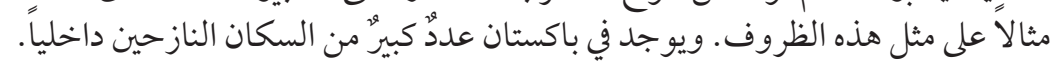

$$
\begin{aligned}
& \text { الأهداف: تحديد مدى انتشار التلعثم بين أطفال السكان النازحين داخلياً في وكالة وزيرستان الشمالية، باكستان. }
\end{aligned}
$$

طرق البحث: شمل هذا المسح المقطعي 400 طفل من الناطقين بلغة الباشتو، تتراوح أعحارهم بين 5-18 عاماً، ومُقيدين في مدارس في وكالة

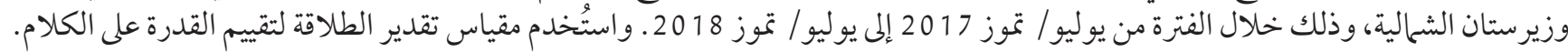

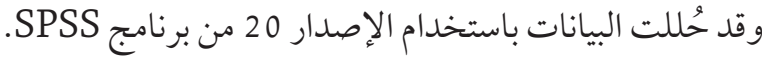

النتائج: بلغت نسبة انتشار التلعثم 11.، وكان التلعثم من الدرجة المتوسطة هو الأكثر انتشارًا. واكتُشفت إصابة خمس فتيات (6.6\%) و و 39 فتى (\% (12.5)

$$
\text { الاستنتاجات: يُعتبر التلعثم من الاضطر ابات الشائعة بين السكان النازحين داخلياً. }
$$

\section{References}

1. Perez HR, Stoeckle J)H. Stuttering Clinical and research update. Can Fam Physician. 2016 Jun;62(6):479-84. PMID:27303004

2. Sari H, Gökdağ H. An analysis of difficulties of children with stuttering enrolled in inclusive classes who encounter in academic and social activities: from their perspectives. J Educ Pract. 2017;8(2):31-43.

3. Fakhrerahimi S, Dehqan A, Bakhshani N. Causes of speech disorders in primary school students of Zahedan. Zahedan J Res Med Sci. 2013;15(2):79-82.

4. Furnham A, Davis S. Involvement of social factors in stuttering: a review and assessment of current methodology. Stammering Res. 2004 Jul 1;1(2):112-22. PMID:18259600

5. Cohen R. The guiding principles on internal displacement: an innovation in international standard setting. Global Governance. 2004;10:459-80.

6. Peek L. Children and disasters: understanding vulnerability, developing capacities, and promoting resilience - an introduction. Children Youth Environ. 2008;18(1):1-29. https://www.jstor.org/stable/10.7721/chilyoutenvi.18.1.0001

7. Oliveira CM, Nogueira PR. Prevalence of risk factors for stuttering among boys: analytical cross-sectional study. Sao Paulo Med J. 2014;132(3):152-7. http://dx.doi.org/10.1590/1516-3180.2014.1323617 PMID:24760215

8. Yairi E, Ambrose N. Epidemiology of stuttering: 21st century advances. J Fluency Disord. 2013 Jun;38(2):66-87. http://dx.doi. org/10.1016/j.jfludis.2012.11.002 PMID:23773662

9. Ajdacic-Gross V, Vetter S, Müller M, Kawohl W, Frey F, Lupi G et al. Risk factors for stuttering: a secondary analysis of a large data base. Eur Arch Psychiatry Clin Neurosci. 2010 Jun;260(4):279-86. http://dx.doi.org/10.1007/s00406-009-0075-4 PMID:19826856

10. Craig A, Hancock K, Tran Y, Craig M, Peters K. Epidemiology of stuttering in the community across the entire life span. J Speech Lang Hear Res. 2002 Dec;45(6):1097-105. http://dx.doi.org/10.1044/1092-4388(2002/088) PMID:12546480

11. Karbasi SA, Fallah R, Golestan M. The Prevalence of Speech Disorder in Primary School Students in Yazd-Iran. Acta Med Iran. 2011;49(1):33-7. PMID:21425069

12. Mohamadi O, Rahimi-Madiseh M, Sedehi M. The prevalence of stuttering, voice disorder, and speech sound disorders in preschoolers in Shahrekord, Iran. Int J Child Youth Family Stud. 2016; 7(3-4):456-71. https://doi.org/10.18357/ijcyfs73-4201616169

13. McKinnon DH, McLeod S, Reilly S. The prevalence of stuttering, voice, and speech-sound disorders in primary school students in Australia. Lang Speech Hear Serv Sch. 2007 Jan;38(1):5-15. http://dx.doi.org/10.1044/0161-1461(2007/002) PMID:17218532

14. Butt GA, Maqbool S, Mahmood A, Azhar A, Idrees H, Iftikhar S. Frequency of stuttering and its common symptoms among children with speech disorders. JRCRS. 2016;4(1):18-21.

15. Oliveira CMC, Cunha D, Santos AC. Risk factors for stuttering in disfluent children with familial recurrence. Audiol Commun Res. 2013;18(1):43-9. https://doi.org/10.1590/S2317-64312013000100009.

16. Adriaensens S, Beyers W, Struyf E. Impact of stuttering severity on adolescents' domain-specific and general self-esteem through cognitive and emotional mediating processes. J Commun Disord. 2015 Nov-Dec;58:43-57. http://dx.doi.org/10.1016/j. jcomdis.2015.10.003 PMID:26484722

17. O'Brian S, Jones M, Packman A, Menzies R, Onslow M. Stuttering severity and educational attainment. J Fluency Disord. 2011 Jun;36(2):86-92. http://dx.doi.org/10.1016/j.jfludis.2011.02.006 PMID:21664527 
18. Keating D, Turrell G, Ozanne A. Childhood speech disorders: reported prevalence, comorbidity and socioeconomic profile. J Paediatr Child Health. 2001 Oct;37(5):431-6. http://dx.doi.org/10.1046/j.1440-1754.2001.00697.x PMID:11885704 